\title{
A felnőttkori neuroinfekciók epidemiológiai és klinikai jellemzőinek vizsgálata a nyugat-dunántúli régióban
}

\author{
Fehér Zsuzsanna dr. ${ }^{1}$ - Toldy Erzsébet dr. ${ }^{2}$ - Schneider Ferenc dr. ${ }^{1}$ \\ ${ }^{1}$ Markusovszky Egyetemi Oktatókórház, Infektológiai Osztály, Szombathely \\ ${ }_{2}^{2}$ Pécsi Tudományegyetem, Egészségtudományi Kar, Diagnosztikai Intézet, \\ Pécs és Kaposvári Képzési Központ, Kaposvár
}

\begin{abstract}
Bevezetés: A diagnosztika fejlődése és az elérhető hatékony antimikrobás szerek ellenére a neuroinfekciók továbbra is magas letalitással járó kórképek.

Célkitüzés: A retrospektív vizsgálat célja, hogy felmérje a nyugat-dunántúli régióban 2010 és 2016 között otthon szerzett neuroinfekciók epidemiológiai és klinikai jellemzőit.

Módszer: Életkor szerinti csoportosításban (<65 év és >65 év) elemeztük 176 beteg adatait.

Eredmények: 81 bakteriális, 91 virális, 1 parazitás és 3 kevert neuroinfekció fordult elő. A leggyakrabban izolált baktérium a Streptococcus pneumoniae (20\%) és a Borrelia burgdorferi (16\%) volt. A virális kórokozók közül a legtöbbször a kullancsencephalitis-vírus (37\%), majd a herpes simplex vírus (10\%) és az enterovírus (7\%) fordult elő. Az összes eset 40\%-ában az etiológia ismeretlen maradt. Az incidencia átlagosan 9,8/100 000 fó/év, a letalitás $12 \%$ volt. Az idősek körében szignifikánsan gyakrabban fordult elő az immunrendszert negatívan befolyásoló tényező $(\mathrm{p}=0,008)$, alacsony felvételi Glasgow Kóma Skála-érték $(\mathrm{p}=0,017)$ és tudatzavar $(\mathrm{p}=0,050)$. Kedvezőtlen klinikai kimenetelt prognosztizált az idős életkor $\left(\mathrm{OR}=6,5 \mathrm{CI}_{95 \%}: 2,5-17,1 ; \mathrm{p}<0,001\right)$, a sérült immunstatus $\left(\mathrm{OR}=3,1 \mathrm{CI}_{95 \%}: 1,2-8,1\right.$; $\mathrm{p}=0,019)$ és az alacsony felvételi Glasgow Kóma Skála-érték $\left(\mathrm{OR}=1,6 \mathrm{CI}_{95 \%}: 1,3-1,9 ; \mathrm{p}<0,001\right)$.

Következtetések: A bakteriális kórképek között továbbra is a $S$. pneumoniae a vezető kórokozó. Régiónkban a kullancsencephalitis incidenciája jelentősen magasabb az országos átlaghoz képest $(2,3$ versus $0,35 / 100000$ fó/év). Vizsgálatunk epidemiológiai és klinikai jellemzést tett lehetővé a régiónkban előforduló neuroinfekciókról.

Orv. Hetil. 2019; 160(40): 1574-1583.
\end{abstract}

Kulcsszavak: epidemiológia, idős életkor, immunszupprimáló tényező, Streptococcus pneumoniae, kullancsencephalitis-vírus

\section{Evaluation of the epidemiological and clinical characteristics of central nervous system infections in adults in the West Pannonian region}

Introduction: Despite advancements in diagnostic capabilities and the availability of effective antimicrobial agents, community-acquired infections of the central nervous system (CNS) are still associated with high mortality rates. Aim: To assess the epidemiological and clinical characteristics of community-acquired CNS infections treated in the West Pannonian region between 2010 and 2016.

Method: Clinical data of 176 patients were retrospectively analysed in two age cohorts: 15 to 65 and more than 65 years of age.

Results: Neuroinfections were found to be bacterial in 81 , viral in 91 , parasitic in 1 and mixed in 3 cases during the observation period. The most frequent bacterial pathogens isolated were Streptococcus pneumoniae (20\%) and Borrelia burgdorferi (16\%). The most frequent viral pathogens isolated were tick-borne encephalitis virus (37\%), herpes simplex virus $(10 \%)$ and enterovirus $(7 \%)$. Aetiology was unknown in 40 percent of all cases. The average incidence rate was $9.8 / 100000$ person/year with a mortality rate of $12 \%$. In the cohort of patients aged $>65$ years, significantly higher frequencies of immunocompromising factors, lower Glasgow Coma Scale values at admission and confusion were observed ( $\mathrm{p}$-values: $0.008,0.017$, and 0.050 , respectively). Prognosis was negatively influenced by low Glasgow Coma Scale values at admission $\left(\mathrm{OR}=1.6 \mathrm{CI}_{95 \%}: 1.3-1.9 ; \mathrm{p}<0.001\right)$, old age $\left(\mathrm{OR}=6.5 \mathrm{CI}_{95 \%}: 2.5-\right.$ $17.1 ; \mathrm{p}<0.001)$ and immunodeficiency $\left(\mathrm{OR}=3.1 \mathrm{CI}_{95 \%}: 1.2-8.1 ; \mathrm{p}=0.019\right)$. 
Conclusions: S. pneumoniae remains the most frequently observed causative bacterial pathogen associated with community-acquired CNS infections. Incidence of tick-borne encephalitis in our county is higher than the national average $(2.3$ versus $0.35 / 100000$ person/year $)$.

Keywords: neuroinfection, epidemiology, old age, immunodeficiency, Streptococcus pneumoniae, tick-borne encephalitis virus

Fehér Zs, Toldy E, Schneider F. [Evaluation of the epidemiological and clinical characteristics of central nervous system infections in adults in the West Pannonian region]. Orv Hetil. 2019; 160(40): 1574-1583.

(Beérkezett: 2019. március 25.; elfogadva: 2019. május 11.)

\begin{abstract}
Rövidítések
ADEM = akut disszeminált encephalomyelitis; ANOVA = (analysis of variance) varianciaanalízis; $\mathrm{BNO}-10=$ Betegségek Nemzetközi Osztályozása, Tizedik revízió; BU-O = Betegellátási Utasítás Orvosoknak; $\mathrm{CI}=($ confidence interval $)$ konfidenciaintervallum; $\mathrm{CMV}=$ cytomegalovirus; $\mathrm{CRP}=\mathrm{C}$-reaktív protein; $\mathrm{CT}=($ computed tomography) számítógépes tomográfia; $\mathrm{EBV}=$ Epstein-Barr-vírus; ECHO-vírus = enteric cytopathogenic human orphan vírus; GCS = Glasgow Kóma Skála; HIV $=$ (human immunodeficiency virus) emberi immunhiányt elöidéző vírus; $\mathrm{HSV}=$ herpes simplex vírus; $\mathrm{IBD}=$ (inflammatory bowel disease) gyulladásos bélbetegség; IBO = intenzív betegellátó osztály; IQ = interkvartilis; JCV = John Cunninghamvírus; $\mathrm{KE}=$ kullancsencephalitis; $\mathrm{KEV}=$ kullancsencephalitisvírus; $\mathrm{LCM}=$ lymphocytás choriomeningitis; $\mathrm{MR}=$ (magnetic resonance) mágneses rezonancia; MRSA = meticillinrezisztens Staphylococcus aureus; $\mathrm{n}$ = esetszám; ns = nem szignifikáns; OR $=$ (odds ratio) esélyhányados; $\mathrm{PCR}=$ (polymerase chain reaction) polimeráz-láncreakció; SLE = (systemic lupus erythematosus) szisztémás lupus erythematosus; tbc = tuberkulózis; $\mathrm{VZV}=$ varicella zoster vírus; $\mathrm{WNV}=($ West-Nile virus $)$ nyugat nílusi vírus
\end{abstract}

Az otthon szerzett neuroinfekció a rendelkezésünkre álló korszerü antibakteriális, illetve antivirális kezelések ellenére is $10-25 \%$-os letalitással járó megbetegedés. A túlélők között számos esetben neurológiai maradványtünet alakul ki (5-40\%), amely rontja a beteg életminőségét, és fokozza az egészségügyi ellátórendszer kiadásait [1-5].

A kórformák jól meghatározott klinikummal, liquoreltérésekkel és mikrobiológiai eredményekkel jellemezhetők, amelyeket az irodalmi adatok alapján az alábbiakban foglalunk össze.

\section{Klinikai jellemzők}

Meningitisben elsődlegesen az agyhártyák érintettek, a klasszikus triász (láz, tarkókötöttség, tudatzavar) csak az esetek 40-70\%-ában fordul elő. Az alacsony felvételi Glasgow Kóma Skála (GCS)-érték és az epilepsziás görcskészség rossz prognózisra utal. Az esetek 10-20\%-ában agyidegbénulás (főként nervus facialis paresis) és fokális góctünetek is felléphetnek $[1,2,6]$. Két kórforma külön- böztethető meg jellegzetes liquorképpel: a purulens meningitis és az enyhébb lefolyású serosus meningitis.

Encephalitisben elsődlegesen az agyállomány mélyebb struktúrája érintett. Gyakran vírusinfekcióra jellemző prodroma előzi meg, illetve maculopapulosus, vesiculosus bőrkiütések kísérhetik. Jellemző klinikai kép a megváltozott tudatállapot, személyiségváltozás, beszéd-, mozgás- és viselkedészavar, fokális góctünetek (hemiparesis, petyhüdt bénulás, paraesthesia), epilepsziás görcsök $[4,7]$.

Meningoencephalitisben elmosódik a határ a fent leírt klinikai tünetek között. A klasszikus meningitisjelek mellett az agyi funkciózavarra, parenchymagyulladásra utaló tünetek is fennállnak.

\section{Laboratóriumi jellemzők}

A liquorvizsgálat során a purulens meningitis, bakteriális eredet mellett szól, ha a cukorkoncentráció $<2,2 \mathrm{mmol} / 1$, a liquor/szérum glükóz hányadosa $<0,4$, a fehérjekoncentráció >220 mg/dl és a fehérvérsejtszám >2000/ $\mathrm{mm}^{3}$ polimorfonukleáris sejtszaporulattal [1]. $50 / \mathrm{mm}^{3}$ alatti fehérvérsejtszám esetén kicsi a valószínúsége az idegrendszeri fertőzésnek, míg $100 / \mathrm{mm}^{3}$ felett már gondolni kell rá [8].

A fenti eltéréseket nagymértékben befolyásolja a beteg életkora, a betegség kezdete óta eltelt idő, a kórokozó fajtája, az előzetes antimikrobás kezelés, az immunvédekezést negatívan befolyásoló kórállapot jelenléte [3].

A serosus meningitisre jellemző a liquor/szérum cukor normális hányadosa, az enyhén emelkedett vagy normális fehérjeszint, a $20-1000 / \mathrm{mm}^{3}$ liquor-fehérvérsejtszám jellemzően lymphocyta-predominanciával [2].

A bakteriális és a virális eredet elkülönítésében segítséget nyújt még a liquor-laktátkoncentráció (>3,8 mmol/l), a szérum-CRP- és -prokalcitoninszint meghatározása $[1,3,9-11]$.

\section{Elöfordulás, kórokozók}

Az otthon szerzett felnőttkori bakteriális meningitisek epidemiológiája az utóbbi évtizedekben megváltozott. Incidenciája a fejlett országokban 3-6/100 000/év. 
Magyarországon évente átlagosan 200 purulens meningitist, 50-75 serosus meningitist és 75-100 encephalitis infectiosát jelentenek [12].

A purulens meningitisek között korábban vezető helyet elfoglaló Haemophilus influenzae okozta infekciók száma a konjugált vakcinák bevezetése óta jelentősen csökkent mind a felnőttek, mind a gyermekek körében. A felnőttek esetében a leggyakoribb purulens kórokozó a Streptococcus pneumoniae ( $50 \%)$, majd a Neisseria meningitidis ( 25-30\%) és harmadik a Listeria monocytogenes $(<5 \%)$. Az esetek közel 40\%-ában a kórokozó ismeretlen marad [1-3]. A kórokozók spektrumát fóként a beteg életkora, a fertőzés felléptének helye (otthon szerzett versus egészségügyi ellátással kapcsolatos) és az immunfunkciókat rontó tényezők befolyásolják. Ez utóbbiak a leggyakrabban a diabetes mellitus, a krónikus alkoholizmus, a szerzett vagy funkcionális asplenia, a malignus daganatos megbetegedések és azok kezelése, a szervtranszplantáció, a veleszületett vagy szerzett immunhiány, a korábban elszenvedett koponyatrauma vagy a beültetett idegrendszeri eszköz (ventriculoperitonealis sönt), az étrendi szokások (pasztörizálatlan tejtermékek fogyasztása). A kezelés szempontjából a terápiás lehetőségek korlátozottak a meticillinrezisztens Staphylococcus aureus (MRSA) és a multirezisztens bélbaktérium okozta neuroinfekció esetén, illetve fenyegető a $S$. pneumoniae- és N. meningitidis-törzsek között terjedő penicillinrezisztencia is [3].

Magyarországon a két leggyakoribb bakteriális kórokú serosus meningitis a Lyme-borreliosis és a leptospirosis [13]. A tuberculosis okozta meningitis basilaris, illetve a Treponema pallidum által okozott neurosyphilis hazánkban ritka kórképek, amelyek fóként a humán immundeficientia vírussal (HIV) fertőzöttekben jelentkeznek. Esetenként a Legionella, a Rickettsia, a Bartonella, a Chlamydia és a Mycoplasma species is okozhat serosus meningitist [2].

Virális eredetű serosus meningitist itthon főként a kullancsencephalitis-vírus (KEV), az enterovírus, a herpes simplex-2 vírus (HSV2), a West-Nile virus (WNV) és a lymphocytás choriomeningitis vírusa (LCM), esetenként a herpes simplex-1 vírus (HSV1, agyvelői érintettség nélkül) infekciója okoz. Az esetek felében a kórokozó ismeretlen marad [5-7].

A virális encephalitisek etiológiája országonként változik. Jellemző az enterovírus genusból az enterovírus speciesek, a Coxsackie-vírus speciesek és ECHO-vírus speciesek, a HSV és a varicella zoster vírus (VZV) predominanciája, ám hazánkban fóképpen a kullancsencephalitis-vírus az egyik leggyakoribb kórokozó. Sporadikusan WNV- és LCM-infekcióra, szezonálisan influenza okozta encephalitisre is számítani kell. Az utóbbi években növekvő morbilliesetszámmal a morbilli-encephalitisek száma is nőni fog. Sérült immunitású betegek esetén egyéb kórokozók is szóba jöhetnek: EpsteinBarr-vírus (EBV), cytomegalovirus (CMV), adenovírus, John Cunningham-vírus (JCV), HIV. A beteg utazási anamnézise meghatározó lehet az adott régióra jellemző kórokozók tekintetében. Az esetek 35-70\%-ában a kórokozó ismeretlen marad [5-7].

$\mathrm{Az}$ irodalmi adatokkal összevetve ismertetjük a 2010 és 2016 között, otthon szerzett felnőttkori idegrendszeri fertőzéssel kórházunkba került betegek életkor szerinti megoszlását, klinikai jellemzőit, kórokát és szövődményeit.

\section{Anyag és módszer}

A Vas megyei Markusovszky Egyetemi Oktatókórház Infektológiai Osztálya regionális centrumként 40 ágyon évente közel 1000 fekvő beteget lát el. Ellátási körzete egész Vas megye és Győr-Moson-Sopron megye egy része, amely 250 ezer felnőtt lakost (>18 év) jelent.

A vizsgált 176 beteg az Infektológiai, a Sürgősségi Betegellátó és a Központi Aneszteziológiai és Intenzív Betegellátó Osztályra került felvételre otthon szerzett neuroinfekció miatt.

A vizsgálatot a Regionális/Intézeti Kutatásetikai Bizottság tudományos munkaként jóváhagyta (az engedélymásolat a szerkesztőségben elérhető).

A betegbevonás során a Betegségek Nemzetközi Osztályozása, Tizedik revízió (BNO-10) kódjai alapján azonosítottuk a bakteriális, vírusos, parazitás, gombaeredetű meningitiseket, encephalitiseket, meningoencephalitiseket és egyéb idegrendszeri fertőző betegségeket (agytályog, epiduralis tályog, ADEM stb.). Az alkalmazott BNO-kódok: G001, G002, G003, G008, G009, G01H0, G02, G03, G04, G05, G06, G07, A17, A27, A32, A39, A6920, A83, A84, A85, A86, A87, A88, A89, A9230, B0030, B0040, B0100, B0110, B0200, B0210, B2610, B2620, B3750, B5090. Kizárási kritérium volt a 14 év alatti életkor (az adott periódusban egy 15 éves beteg fordult elő a 14 és 18 év közötti korosztályban, akit a vizsgálatba bevontunk), valamint a feltételezhető vagy bizonyított nosocomialis eredet (tartós hospitalizáció vagy mútét kapcsán fellépő idegrendszeri fertőzés).

\section{A diagnózis megállapitása, rögzitett adatok}

A diagnosztikai és terápiás stratégiát a Betegellátási Utasítás Orvosoknak (BU-O-22, BU-O-24, BU-O-NE-10) intézményi protokoll alapján terveztük meg. Meningitisként határoztuk meg a jellemző klinikai tünetekkel (láz, fejfájás, tudatzavar, meningealis izgalmi tünetek), liquor általános és mikrobiológiai vizsgálattal (bakteriológiai tenyésztés; Gram-festés; latexagglutináció; esetenként bakteriális PCR; esetenként lues, Leptospira, Chlamydia, Mycoplasma, Coxiella, Borrelia, tularaemia szerológiai vizsgálata, gombatenyésztés, tbc-tenyésztés és PCR, hemokultúra) alátámasztott infekciókat [3]. Az encephalitishez soroltuk a megváltozott tudatállapot mellett fokális neurológiai kórjeleket mutató, liquor általános és mikrobiológiai vizsgálattal (szerológia, PCR), illetve na- 
tív/kontrasztanyagos MR-vizsgálattal alátámasztott eseteket [4]. A vírusos etiológia tisztázására esetenként egyénileg meghatározva entero-, adenovírus, HSV, VZV PCR-vizsgálata, EBV, HSV, VZV, KE, mumps, LCM, HIV, WNV szerológiai vizsgálata történt. Multiplex PCR-vizsgálat kórházunk számára nem érhető el. Meningoencephalitis esetén a klasszikus meningealis izgalmi jelek mellett encephalitisre utaló klinikai, liquor- és képalkotó eltéréseket észleltünk. A tudatzavar meghatározása során a tudat vigilitasi (hypnoid) és integritási (nem hypnoid) zavarait is figyelembe vettük.

A bakteriális és vírusos eredet elkülönítésében a mikrobiológiai vizsgálati eredmények, illetve azok negativitása esetén a szérum-CRP-, a szérumprokalcitonin-meghatározás és a vérképlelet is segített $[1,3,9,10]$. A diagnosztikus lumbálpunkció előtt a betegek harmadánál történt natív CT-vizsgálat. A kontrasztanyagos CTvizsgálatokat, a natív és kontrasztanyagos MR-vizsgálatok szükségességét a radiológusokkal konzultálva egyénileg határoztuk meg.

Vizsgálatunk során rögzítettük az epidemiológiai és a klinikai jellemzőket, a liquor általános vizsgálat, a bakteriális tenyésztés, az esetenkénti szerológiai és PCR-vizsgálat, valamint a hemokultúra eredményét, a CT- és az MR-vizsgálat, illetve bakteriális kórok esetén a mannitolés a dexametazonadás tényét, az elbocsátáskor és a féléves ellenőrzéskor észlelt statust. Agynyomáscsökkentő kezelésre a betegek általánosan $2 \times 20$ gr mannitolt kaptak intravénásan 5-7 napig, amennyiben koponyaüri nyomásfokozódásra utaló jel vagy tünet volt. A szteroidkezelésről egyénileg döntöttünk, dózisa intravénásan $0,15 \mathrm{mg} / \mathrm{ttkg}$ napi 3-4-szer adagolva 5-7 napig. Az intézeti protokoll nem tér ki részletesen az utánkövetés módszerére és gyakoriságára. A betegek neurológiai statusát, fó maradványtüneteiket rögzítettük hazabocsátásukkor $(\mathrm{n}=176)$, illetve meghatározott időpontokban (1., 3., 6., 12. hónap) történt ambuláns kontrollvizsgálat alkalmával $(\mathrm{n}=49)$. Az utánkövetés során a betegek 75\%-a nem jelent meg a féléves kontrollvizsgálaton.

\section{Az adatok feldolgozása, statisztikai módszerek, epidemiológiai mutatók}

Az életkor szerint a betegeket két csoportba osztottuk: a 14-64 év közöttiek az I. csoportba, a betöltött 65 évnél idősebbek a II. csoportba tartoztak. A bakteriális és vírusos eredetû megbetegedéseknél az életkor függvényében vizsgáltuk a klinikai jellemzőket, a liquorleletet, az etiológiát és a kimenetelt. Az elemzésből kizártuk a 3 kevert (KE és Borrelia koinfekciója) és az 1 parazitás (Plasmodium falciparum) fertőzésben szenvedő beteget.

A nem normáleloszlást mutató (Kolmogorov-Szmirnov-teszt szerint $\mathrm{p}<0,05)$, illetve a kis elemszámú változóinkat mediánban $(\mathrm{M})$ és az alsó és felső kvartilishez tartozó medián értékekkel (IQ25-IQ75) közöltük. A két korcsoport közötti eltérést folytonos változó esetén Mann-Whitney-féle U-teszttel, a kettőnél több kate- góriába sorolható csoportok összehasonlítását KruskallWallis ANOVA-teszttel végeztük. A dichotom jellemzők gyakoriságának összevetését kontingenciatáblázat segítségével, khi-négyzet-teszttel $(<5$ elemszám esetén Fischer-féle egzakt teszttel) végeztük el. A betegség kimenetelét mint függő (él-meghalt) változót, a független változók (nem, életkor, felvételi GCS-érték, az immunrendszert deprimáló betegség megléte) figyelembevételével bináris logisztikus regresszióval ('forward' módszerrel, alapszintű p-érték 0,05, a kizáró $\mathrm{p}=0,1$ valószínúség mellett) lépcsőzetesen, egyenként elemeztük. A szignifikánsnak bizonyult független változókat egy modellen belül (egymásra kontrollálva) is vizsgáltuk. Az esélyhányadosokat $(\mathrm{OR}) \pm 95 \%$-os konfidenciaintervallummal definiáltuk.

Az eredményeket csak a $\mathrm{p}<0,05$ értéknél tekintettük szignifikánsnak, de feltüntettük a szignifikanciát megközelítő értékeket is. Az értékelésekhez SPSS statisztikai programcsomagot (version 21, IBM Corporation, Armonk, NY, Amerikai Egyesült Államok [USA]), valamint Statistica for Windows 7 (version 10, StatSoft Inc., Tulsa, OK, USA) programcsomagot használtunk. Az incidencia meghatározásához az alábbi képletet használtuk: új esetek száma/az érintett populáció átlagos száma × 100 000/év. A letalitás meghatározása a [neuroinfekció miatt meghaltak száma/neuroinfekcióban megbetegedettek $\times 100$ ] képlettel történt.

\section{Eredmények}

A 7 év során 176 beteget láttunk el otthon szerzett neuroinfekció miatt. Az esetek 75\%-a $(\mathrm{n}=132) 65$ év alatti volt, az idősek csoportjába ( 65 év felett) 44 beteg tartozott. A betegek 55\%-a férfi ( $\mathrm{n}=96 ; 44$ év, min.: 16 év, max.: 83 év) volt. A nők életkori mediánja (53 év, 18-89 év) magasabb volt, de nem tért el szignifikánsan ( $\mathrm{p}=$ $0,510)$ a férfiakétól. Az életkorok eloszlása nem mutatott normáleloszlást (1. ábra). A nemek arányát, az immunstatust, az elvégzett képalkotó vizsgálatokat és a klinikai diagnózisok megoszlását az etiológia szerint az 1. táblázat összesíti. Az immunrendszert kedvezőtlenül befolyásoló leggyakoribb tényező a diabetes mellitus ( $\mathrm{n}=14 ; 33 \%$ ), a krónikus alkoholizmus és következményes májcirrhosis $(\mathrm{n}=14 ; 33 \%)$, a malignus daganat és annak kezelése $(\mathrm{n}=7 ; 17 \%)$ volt. Egyéb esetekben $(\mathrm{n}=$ 7; 17\%) vesetranszplantáció, krónikus veseelégtelenség, Down-szindróma, autoimmun betegség, illetve gyulladásos bélbetegség miatti kezelés állt a csökkent immunitás hátterében.

A panaszok kezdete és a kórházba kerülés között eltelt idő alapján megkülönböztettünk akut és krónikus kórképeket (krónikus $>4$ hét). Az utóbbiba négy neuroborreliosis és egy kullancsencephalitis (ebben az esetben a kórházi felvétel és a panaszok kezdete között 5 hét telt el) volt besorolható $(\mathrm{n}=5)$.

A bakteriális neuroinfekciók fóbb jellemzőit a 2. táblázat összesíti. 


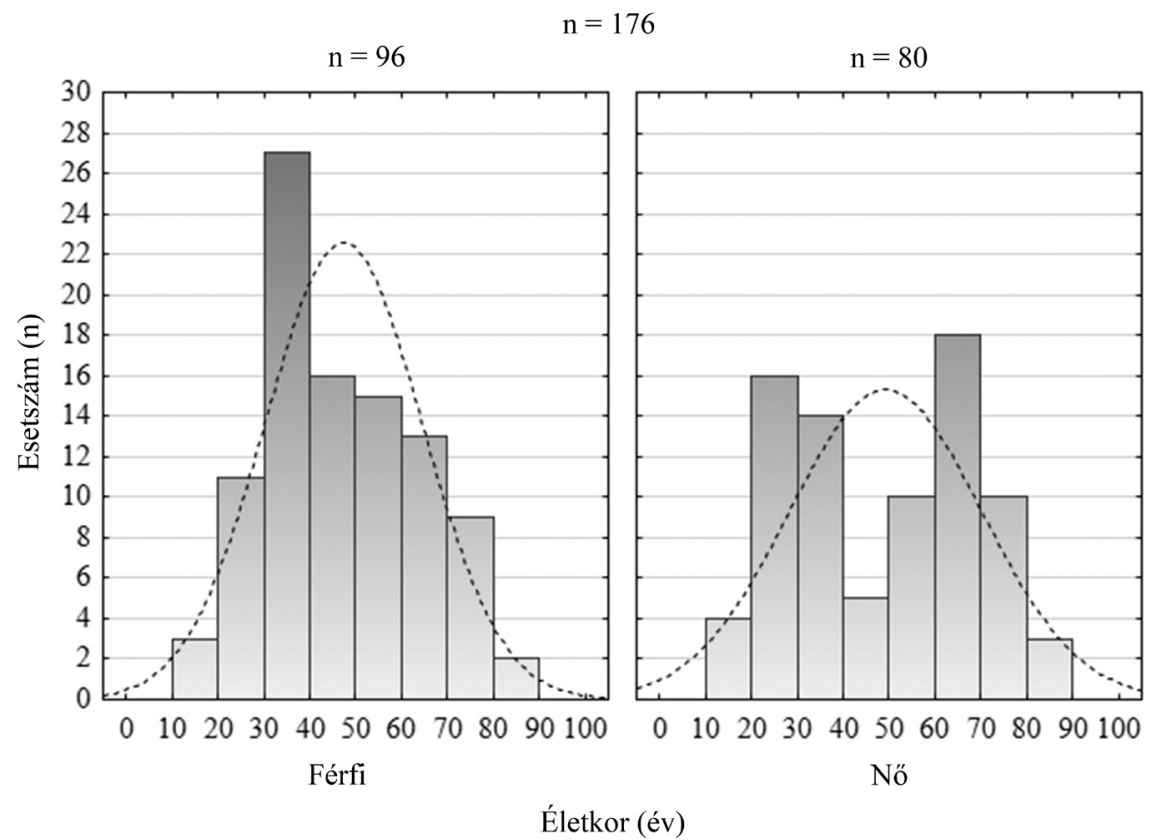

1. ábra | Az életkorok nemek szerinti hisztogramja

A nemek aránya és immunológiai állapotuk szempontjából nem volt statisztikai különbség a két korcsoport között.

A fiatalok közül többen panaszkodtak fejfájásra $(\mathrm{p}=$ $0,004)$. Az időseket szignifikánsan alacsonyabb felvételi GCS-érték $(\mathrm{p}=0,017)$ és több neurológiai gócjel $(\mathrm{p}=$ $0,041)$ jellemezte. Esetükben magasabb arányban fordult eló tudatzavar $(p=0,050)$. A tünetek közül a láz, fejájás, tudatzavar és tarkókötöttség kombinációja nem mutatott szignifikáns eltérést a két csoportban.
65 év felett a liquor/szérum cukor hányadosa szignifikánsan alacsonyabb volt $(\mathrm{p}=0,041)$. Egyéb jellemzők tekintetében a két korcsoport között statisztikailag igazolható eltérést nem találtunk (Gram-festés, latexagglutináció, pozitív tenyésztési lelet, pozitív hemokultúralelet, Borrelia- és egyéb szerológiai pozitivitás).

A mikrobiológiailag igazolt esetek közül a leggyakoribb kórokozó mindkét korcsoportban a $S$. pneumoniae volt. A 17 igazolt $S$. pneumoniae-infekcióból 11 esetben történt szerotipizálás. Öt esetben 3 -as, 2 betegben $15 \mathrm{C}$-,

1. táblázat |Az esetek főbb jellemzői az etiológiai csoportosításban

\begin{tabular}{|c|c|c|c|c|c|}
\hline & $\begin{array}{l}\text { Összes beteg } \\
\begin{array}{c}(\mathrm{n}=176) \\
\mathrm{n}(\%)\end{array}\end{array}$ & $\begin{array}{c}\text { Bakteriális } \\
(\mathrm{n}=81) \\
\mathrm{n}(\%)\end{array}$ & $\begin{array}{c}\text { Virális } \\
\begin{array}{c}(\mathrm{n}=91) \\
\mathrm{n}(\%)\end{array}\end{array}$ & $\begin{array}{c}\text { Kevert } \\
(\mathrm{n}=3) \\
\mathrm{n}(\%)\end{array}$ & $\begin{array}{c}\text { Parazitás } \\
(\mathrm{n}=1) \\
\mathrm{n}(\%)\end{array}$ \\
\hline \multicolumn{6}{|l|}{ Nemek } \\
\hline férfi & $96(55)$ & $44(54)$ & $49(54)$ & 2 & 1 \\
\hline nő & $80(45)$ & $37(46)$ & $42(46)$ & 1 & - \\
\hline Sérült immunitás & $39(23)$ & $30(37)$ & $9(10)$ & - & - \\
\hline \multicolumn{6}{|l|}{ Képalkotó vizsgálat } \\
\hline natív CT & $40(23)$ & $28(35)$ & $12(13)$ & - & - \\
\hline natív + kontrasztos CT & $136(77)$ & $70(86)$ & $62(68)$ & 3 & 1 \\
\hline natív + kontrasztos MR & $60(34)$ & $23(28)$ & $37(41)$ & - & - \\
\hline \multicolumn{6}{|l|}{ Klinikai diagnózis } \\
\hline meningitis & $18(10)$ & $8(10)$ & $10(11)$ & - & - \\
\hline encephalitis & $21(12)$ & $3(4)$ & $18(20)$ & - & - \\
\hline meningoencephalitis & $128(73)$ & $62(77)$ & $62(68)$ & 3 & 1 \\
\hline egyéb: agytályog & $6(3)$ & $6(7)$ & - & - & - \\
\hline epiduralis tályog & $2(1)$ & $2(2)$ & - & - & - \\
\hline ADEM & $1(1)$ & - & $1(1)$ & - & - \\
\hline
\end{tabular}

ADEM = akut disszeminált encephalomyelitis; $\mathrm{CT}$ = számítógépes tomográfia; $\mathrm{MR}$ = mágneses rezonancia; $\mathrm{n}=$ esetszám 
Korcsoportfüggő eltérések a bakteriális kórokú betegekben

\begin{tabular}{|c|c|c|c|}
\hline $\begin{array}{l}\text { Összes beteg } \\
(\mathrm{n}=81)\end{array}$ & $\begin{array}{l}\text { I. csoport } \\
(\mathrm{n}=53) \\
\mathrm{n}(\%)\end{array}$ & $\begin{array}{l}\text { II. csoport } \\
\begin{array}{c}(\mathrm{n}=28) \\
\mathrm{n}(\%)\end{array}\end{array}$ & $\mathrm{p}$ \\
\hline \multicolumn{4}{|l|}{ Klinikai jellemzők } \\
\hline láz & $25(47,0)$ & $14(50,0)$ & ns \\
\hline fejfájás & $45(90,5)$ & $18(64,0)$ & 0,004 \\
\hline tudatzavar & $30(57,0)$ & $22(79,0)$ & 0,050 \\
\hline felvételi GCS-érték & $15(13-15)^{*}$ & $13(10-15)^{*}$ & 0,017 \\
\hline egyéb neurológiai kórjel & $3(6,0)$ & $8(29,0)$ & 0,007 \\
\hline \multicolumn{4}{|l|}{ Liquorlelet } \\
\hline $\begin{array}{l}\text { liquorfehérje }(\mathrm{mg} / \mathrm{dl}) \\
(\mathrm{n}=76)\end{array}$ & $\begin{array}{c}160 \\
(96-332)^{*}\end{array}$ & $\begin{array}{c}234 \\
(103-493)^{*}\end{array}$ & ns \\
\hline $\begin{array}{l}\text { liquor/szérum glükóz } \\
\text { hányados }(n=67)\end{array}$ & $\begin{array}{c}0,44 \\
(0,11-0,55)^{*}\end{array}$ & $\begin{array}{c}0,15 \\
(0,01-0,36)^{*}\end{array}$ & 0,041 \\
\hline $\begin{array}{l}\text { liquor-fehérvérsejtszám } \\
(\mathrm{x} / 3 \text { fvs/látótér) }(\mathrm{n}=77)\end{array}$ & $\begin{array}{c}3000 \\
(960-15000)^{*}\end{array}$ & $\begin{array}{c}872,5 \\
(154-4150)^{*}\end{array}$ & ns \\
\hline \multicolumn{4}{|l|}{ Etiológia } \\
\hline Streptococcus pneumoniae & $11(20,5)$ & $6(21,0)$ & ns \\
\hline Neisseria meningitidis** & $3(5,5)$ & $1(3,5)$ & ns \\
\hline Listeria sp. & $1(2,0)$ & $1(3,5)$ & ns \\
\hline Egyéb Gram-pozitív* * * & $6(11,0)$ & $1(3,5)$ & ns \\
\hline Gram-negatív**** & $2(3,5)$ & $1(3,5)$ & ns \\
\hline Haemophilus influenzae & $0(0,0)$ & $1(3,5)$ & ns \\
\hline Mycobacterium tuberculosis & $0(0,0)$ & $1(3.5)$ & ns \\
\hline Polimikrobás***** & $1(2,0)$ & $0(0,0)$ & ns \\
\hline Borrelia burgdorferi & $6(11,0)$ & $5(18,0)$ & ns \\
\hline Leptospira sp. ${ }^{* * * * *}$ & $1(2,0)$ & $0(0,0)$ & ns \\
\hline Ismeretlen & $22(41,5)$ & $11(39,0)$ & ns \\
\hline \multicolumn{4}{|l|}{$\begin{array}{l}\text { Agynyomáscsökkentő } \\
\text { kezelés }\end{array}$} \\
\hline dexametazon & $46(87,0)$ & $18(64,0)$ & ns \\
\hline mannitol & $41(77,0)$ & $16(57,0)$ & 0,058 \\
\hline
\end{tabular}

* medián (IQ25-IQ75) interkvartilis range

${ }^{*}$ C-csoportú $(\mathrm{n}=1)$, B-csoportú $(\mathrm{n}=3)$

***S. aureus $(\mathrm{n}=2), S$. epidermidis $(\mathrm{n}=1), S$. pyogenes $(\mathrm{n}=2)$ és S. mitis $(\mathrm{n}=1)$, G-csoportú Streptococcus $(\mathrm{n}=1)$

**** Morganella morganii $(\mathrm{n}=1)$, Moraxella catarrhalis $(\mathrm{n}=1)$ és Acinetobacter baumannii $(\mathrm{n}=1)$

***** Escherichia coli, Klebsiella oxytoca, alfa-hemolizáló Streptococcus, Enterococcus sp. koinfekciója egy ventriculoperitonealis söntöt viselö betegben

******PCR-technikával Leptospira hebdomadis

GCS = Glasgow Kóma Skála; n = esetszám; ns = nem szignifikáns; $\mathrm{p}=$ szignifikanciaszint

a többiekben szórványosan 7F-, 9N-, 10A- és 22F-törzs fordult elő. A második leggyakoribb kórképként a neuroborreliosist azonosítottuk. Egy 65 év feletti nőbetegben a saválló festés, PCR és tenyésztés meningitis basilaris tuberculosát igazolt, de a gátlószeres kezelés ellenére exitált. Az esetek közel 40\%-ában nem tudtunk kórokozót izolálni, aminek oka az előzetes antimikrobás kezelés, illetve a nem megfelelő mikrobiológiai mintatárolás volt.

A vírusos eredetû neuroinfekciók főbb jellemzőit a 3. táblázat foglalja össze.

A vírusos eredetû́ csoportban a nemek arányának szempontjából nem volt különbség a fiatal és az idős korosztály között. Sérült immunitású beteg szignifikánsan több volt 65 év felett $(p=0,008)$. Több fiatalnál észleltünk lázat $(\mathrm{p}=0,03)$ és agyidegtünetet. Az idősekben szignifikánsan jellemzőbb volt a tudatzavar és az alacsonyabb felvételi GCS-érték $(\mathrm{p}=0,05)$. Magasabb liquorfehérvérsejtszámot észleltünk a fiatalokban $(\mathrm{p}=0,052)$. Szignifikánsan több képalkotó vizsgálatra került sor az etiológia tisztázására az idősebb korosztályban (natív CT esetén $44 \%$ versus $12 \%, \mathrm{p}=0,006$; natív/kontrasztos $\mathrm{MR}$ esetén $69 \%$ versus $35 \%, \mathrm{p}=0,013$ ).

3. táblázat | Korcsoportfüggő eltérések a virális kórokú betegekben

\begin{tabular}{|c|c|c|c|}
\hline $\begin{array}{l}\text { Összes beteg } \\
(\mathrm{n}=9 \mathrm{l})\end{array}$ & $\begin{array}{l}\text { I. csoport } \\
(\mathrm{n}=75) \\
\mathrm{n}(\%)\end{array}$ & $\begin{array}{l}\text { II. csoport } \\
(\mathrm{n}=16) \\
\mathrm{n}(\%)\end{array}$ & $\mathrm{p}$ \\
\hline \multicolumn{4}{|l|}{ Klinikai jellemzők } \\
\hline láz & $50(67,0)$ & $6(38,0)$ & 0,030 \\
\hline fejfájás & $66(88,0)$ & $13(81,0)$ & ns \\
\hline tudatzavar & $23(31,0)$ & $12(75,0)$ & 0,002 \\
\hline felvételi GCS-érték & $15(15-15)^{*}$ & $14(13-15)^{*}$ & 0,05 \\
\hline agyidegtünet & $25(33,0)$ & $2(13,0)$ & ns \\
\hline bőrkiütés & $10(13,0)$ & $5(31,0)$ & ns \\
\hline
\end{tabular}

Liquorlelet**

$\begin{array}{lccc}\text { liquorfehérje }(\mathrm{mg} / \mathrm{dl}) & \begin{array}{c}68 \\ (50-83,7)^{*}\end{array} & \begin{array}{c}68 \\ (44-103)^{*}\end{array} & \mathrm{~ns} \\ \begin{array}{l}\text { liquor/szérum glükóz } \\ \text { hányados }\end{array} & 0,52 & 0,49 & \mathrm{~ns} \\ \begin{array}{l}\text { liquor-fehérvérsejtszám } \\ (\mathrm{x} / 3 \text { fvs/látótér) }\end{array} & 384-0,59)^{*} & (0,44-0,64)^{*} & \\ \text { tiológia } & (180-756)^{*} & (8-445)^{*} & 0,052 \\ \text { HSV1,2 } & & & \\ \text { VZV } & 7(9,0) & 2(12,5) & \mathrm{ns} \\ \text { WNV } & 3(4,0) & 2(12,5) & \mathrm{ns} \\ \text { KE } & 1(1,5) & 1(6,0) & \mathrm{ns} \\ \text { egyéb: } & 28(37,0) & 4(25,0) & \mathrm{ns} \\ \text { EBV + enterovírus } & & & \\ \text { mumps (oltatlan) } & 1(1,5) & 0(0,0) & - \\ \text { adenovírus } & 1(1,5) & 0(0,0) & - \\ \text { enterovírus } & 1(1,5) & 0(0,0) & - \\ \text { ismeretlen } & 5(7,0) & 1(6,0) & - \\ & 28(37,0) & 6(38,0) & \mathrm{ns}\end{array}$

* medián (IQ25-IQ75) interkvartilis range

**az I. csoportban két betegnek nem volt liquorvizsgálata

EBV = Epstein-Barr-vírus; GCS = Glasgow Kóma Skála; HSV = herpes simplex vírus; $\mathrm{KE}=$ kullancsencephalitis; $\mathrm{n}$ = esetszám; $\mathrm{ns}=$ nem szignifikáns; $\mathrm{p}=$ szignifikanciaszint; $\mathrm{VZV}=$ varicella zoster vírus; $\mathrm{WNV}=$ West-Nile virus 
A leggyakoribb kórokozó a kullancsencephalitis-vírus, majd a HSV volt. Mindkét korcsoportban az esetek közel 40\%-ában a kórokozó ismeretlen maradt.

Több idős beteg került intenzív osztályra, és szignifikánsan hosszabb volt esetükben a kórházi ápolás is ( $\mathrm{p}=$ 0,002 ). A legfóbb virális maradványtünet a motoros deficit, agyidegbénulás, perzisztáló fejfájás vagy egyéb fájdalom, ataxia és kognitív diszfunkció volt (4. táblázat). A kimenetel szempontjából az idős korosztályban a halálozás aránya szignifikánsan $(\mathrm{p}=0,002)$ magasabb volt. A fiatalok nagy része szövődménymentesen gyógyult, ám mindkét korcsoportban az esetek 30\%-ában találtunk

4. táblázat |A kórházi ápolási napok és gyógyulási eredmények

\begin{tabular}{|c|c|c|c|}
\hline $\begin{array}{l}\text { A) Bakteriális infekció } \\
(\mathrm{n}=81)\end{array}$ & $\begin{array}{l}\text { I. csoport } \\
(\mathrm{n}=53) \\
\mathrm{n}(\%)\end{array}$ & $\begin{array}{l}\text { II. csoport } \\
\begin{array}{c}(\mathrm{n}=28) \\
\mathrm{n}(\%)\end{array}\end{array}$ & $\mathrm{p}$ \\
\hline \multicolumn{4}{|l|}{ Kimenetel } \\
\hline IBO-kezelés & $21(40)$ & $16(57)$ & ns \\
\hline $\begin{array}{l}\text { IBO-on eltöltött idő } \\
\text { (nap) }\end{array}$ & $6(4-10)^{*}$ & $7(4-17)^{*}$ & ns \\
\hline $\begin{array}{l}\text { összes kórházi ápolás } \\
\text { (nap) }\end{array}$ & $15(12-23)^{*}$ & $18(12-21)^{*}$ & ns \\
\hline \multicolumn{4}{|l|}{ kimenetel emissziókor: } \\
\hline 1. teljes gyógyulás & $33(62)$ & $8(29)$ & ns \\
\hline 2. maradványtünetes & $15(28)$ & $9(32)$ & ns \\
\hline 3. exitus & $5(10)$ & $11(39)$ & 0,002 \\
\hline $\begin{array}{l}\text { kimenetel fél év után: } \\
(\mathrm{n}=24)\end{array}$ & $(\mathrm{n}=15)$ & $(\mathrm{n}=9)$ & \\
\hline 1. gyógyult & 1 & 2 & - \\
\hline 2. maradványtünetes & 10 & 1 & - \\
\hline 3. nem ismert & 4 & 6 & - \\
\hline $\begin{array}{l}\text { B) Virális kórok } \\
(\mathrm{n}=91)\end{array}$ & $\begin{array}{l}\text { I. csoport } \\
(\mathrm{n}=75) \\
\mathrm{n}(\%)\end{array}$ & $\begin{array}{l}\text { II. csoport } \\
\begin{array}{c}(\mathrm{n}=16) \\
\mathrm{n}(\%)\end{array}\end{array}$ & $\mathrm{p}$ \\
\hline \multicolumn{4}{|l|}{ Kimenetel } \\
\hline IBO-kezelés & $6(8)$ & $4(25)$ & ns \\
\hline IBO-n eltöltött idő (nap) & $8(1-15)$ * & $4(2-7)^{*}$ & ns \\
\hline $\begin{array}{l}\text { összes kórházi ápolás } \\
\text { (nap) }\end{array}$ & $10(9-15)$ * & $17(13-22)^{*}$ & 0,002 \\
\hline \multicolumn{4}{|l|}{ kimenetel emissziókor: } \\
\hline 1. teljes gyógyulás & $54(72)$ & $8(50)$ & ns \\
\hline 2. maradványtünetes & $19(25)$ & $6(38)$ & ns \\
\hline 3. exitus & $2(3)$ & $2(12)$ & ns \\
\hline $\begin{array}{l}\text { kimenetel fél év után: } \\
(\mathrm{n}=25)\end{array}$ & $(\mathrm{n}=19)$ & $(\mathrm{n}=6)$ & \\
\hline 1. gyógyult & 6 & 1 & - \\
\hline 2. maradványtünetes & 10 & 5 & - \\
\hline 3. nem ismert & 3 & 0 & - \\
\hline
\end{tabular}

*medián (IQ25-IQ75) interkvartilis range; n = esetszám; ns = nem szignifikáns; $\mathrm{p}$ = szignifikanciaszint

IBO = intenzív betegellátó osztály neurológiai maradványtünetet elbocsátáskor. A leggyakrabban agyidegbénulást, motoros deficitet, perzisztáló fejfájást vagy egyéb fájdalmat észleltünk.

\section{Egyéb kórokú neuroinfekciók}

Egy 33 éves férfi, aki meningoencephalitis, szeptikus sokk miatt került felvételre, parazitás megbetegedésben szenvedett. Az ellátás 36. órájában minden terápiás erőfeszítés ellenére exitált. Post mortem a szövettani vizsgálat $P$. falciparum okozta cerebralis maláriát igazolt. A családtagok utólag elmondták, hogy a beteg a közelmúltban Elefántcsontparton tartózkodott úgy, hogy gyógyszeres profilaxisban nem részesült.

A három kevert infekció neuroborreliosis és kullancsencephalitis együttes előfordulása volt ( 2 férfi, 1 nő). Gombaeredetü idegrendszeri kórkép az adott időszakban nem fordult elő kórházunkban.

\section{A betegség kimenetelének elemzése, a kimenetel prognoszikai faktorai}

A teljes betegpopulációban a klinikai kimenetel predikcióját regressziós analízissel vizsgáltuk. A 65 évnél magasabb életkor $(\mathrm{OR}=6,5 \mathrm{CI}: 2,5-17,1 ; \mathrm{p}<0,001)$, az alacsonyabb felvételi GCS-érték ( $\mathrm{OR}=1,6 \mathrm{CI}$ : 1,3-1,9; $\mathrm{p}<0,001)$ és az immunrendszert deprimáló krónikus betegség $(\mathrm{OR}=3,1 \mathrm{CI}: 1,2-8,1 ; \mathrm{p}=0,019)$ szignifikánsan kedvezőtlen klinikai kimenetelt prognosztizál, vagyis a halálozás esélyét e három tényező 1,6-6,5-szeresére növelte. Ha a három tényezőt együttesen vizsgáltuk a regressziós modellben, akkor a letalitási esélyt a 65 évnél idősebb életkor $(\mathrm{OR}=4,1 \mathrm{CI}: 1,4-11,9 ; \mathrm{p}=0,01)$ és a felvételi GCS-érték $(\mathrm{OR}=1,5 \mathrm{CI}: 1,2-1,8 ; \mathrm{p}<0,0001)$ befolyásolta szignifikánsan, míg az immunszupprimáló tényezők ezek mellett nem bizonyultak szignifikánsnak $(\mathrm{p}=0,487)$.

\section{Megbeszélés}

Az otthon szerzett neuroinfekciók mielőbbi felismerése, kezelése napjainkban is kiemelkedő fontosságú. A betegség letalitása az utóbbi évtizedekben sem csökkent, a rendelkezésünkre álló korszerű antimikrobás kezelések mellett sem, így fontosnak tartottuk, hogy felmérjük az elmúlt 7 évben neuroinfekcióval osztályunkra felvett betegek klinikumát, kórokát, epidemiológiáját és a betegség kimenetelét.

Retrospektív vizsgálatunk pontos képet nyújt a nyugat-magyarországi régióban előforduló, otthon szerzett idegrendszeri fertőző betegségekről. A betegség incidenciája 6,9-11,8 fö/100 000/év között mozgott a teljes 7 év alatt (2. ábra) [14]. 2011-től 2014-ig kissé emelkedett a betegszám mind a bakteriális, mind a virális csoportban, fóként a 65 év alattiak csoportjában, ám ezt magyarázó, járványügyi jelentőséggel bíró esemény nem fordult elő. A letalitás 12,3\% (6,7\%-18,5\%) körül alakult 


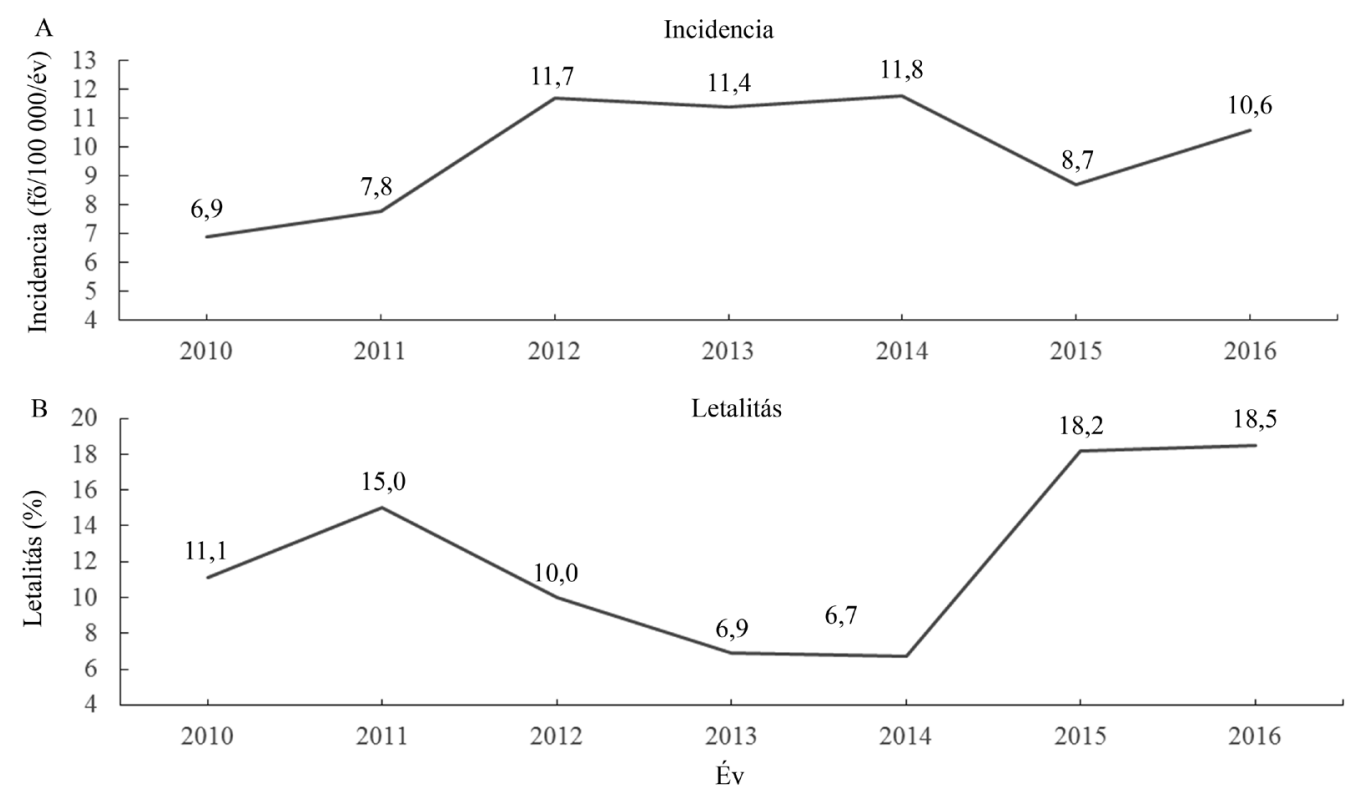

2. ábra

| A neuroinfekciók incidenciája (A) és letalitása (B) a vizsgált 7 évben

a vizsgálat időszakában, ami a nemzetközi tanulmányokkal összhangban van $[11,15-18]$. Az utolsó két év jelentősebb halálozását az idős korcsoport esetszám-növekedése okozta. Esetükben eleve rosszabb prognózisra számíthatunk.

Az etiológiát $~ 60 \%$-ban sikerült tisztázni mind a bakteriális, mind a virális csoportban, ami más országok eredményeihez hasonló $[11,15,19]$. A vezető bakteriális kórokozó mindkét korcsoportban a $S$. pneumoniae volt. A leggyakrabban izolált szerotípus a 3-as volt, ami az országos trendnek megfelel [12]. A második leggyakoribb bakteriális kórképet a Borrelia burgdorferi okozta, melyet a régiónkban magas kullancsfertőzöttségi arány magyaráz [13]. A nemzetközi irodalomban 2. és 3. helyre sorolt $N$. meningitidis- és Listeria-infekciók vizsgálatunkban sporadikusak voltak [1-3]. A N. meningitidis-törzsek szerotípusos megoszlása évról évre változott (B-, illetve C-szerotípus-dominanciával). Erdem és mtsai 2017-es multicentrikus vizsgálatában világviszonylatban előkelő helyet foglalt el a meningitis basilaris tuberculosa [18]. Hazánkra az alacsony tbc- és HIV-incidencia miatt ez nem jellemző [12]. Lakatos és mtsai 2011-es magyar közleményében a vizsgált 11 évben 15 eset fordult elő. A betegek közel felében nem volt kimutatható immunszupprimáló tényező, HIV-negatív volt minden páciens. A klinikumra a larvált, tünetszegény kezdet, a progrediáló, ám torpid lefolyás volt jellemző [20]. A $H$. influenzae korábbi vezető szerepe a konjugált vakcinák bevezetésének köszönhetően Magyarországon is jelentősen csökkent. A Pneumococcus-vakcináció hatása a felnőtt populációban még várat magára, ám a 0-4 éves korosztályban csökken a baktérium okozta meningitis és pneumonia aránya [21].

Vizsgálatunkban a bakteriális meningitis esetén az idős korosztályra jellemző a klinikum szegénysége, a súlyo- sabb felvételi állapot, amely a kimenetelt a későbbiekben jelentősen befolyásolja. Az alacsonyabb felvételi GCS-érték és a görcskészség más tanulmányokban ugyancsak magas letalitással járt, mint ahogy ezt saját adataink is igazolták [15, 17]. A liquor általános és mikrobiológiai vizsgálat során az idős korosztályt a liquor/szérum glükóz szignifikánsan alacsonyabb hányadosa jellemezte. Esetükben a liquor-fehérvérsejtszám is alacsonyabb volt, de ez a szignifikanciaszintet nem érte el. Felmérésünkben alacsonyabb volt a liquor mikrobiológiai pozitivitás (tenyésztés, hemokultúrapozitivitás) más tanulmányokhoz viszonyítva (40\% vs. $60-70 \%)$ [11, 15, 18]. Ennek oka nem ismert pontosan, de feltételezhető, hogy az előzetes antimikrobás kezelésekról nem minden esetben állt rendelkezésünkre információ. Sok esetben a feltételezett bakteriális infekció ellenére a hemokultúravétel sajnálatosan elmaradt, illetve a minták mikrobiológiai laboratóriumba juttatásáig sok esetben nem volt megfelelő a tárolás. A betegek közel harmadában készült a lumbálpunkció előtt natív CT-vizsgálat a kisagyi beékelődés veszélyének kizárására, illetve még magasabb volt a kontrasztos vizsgálatok aránya. Számos tanulmány felhívja a figyelmet az indokolatlanul kért koponya-CT-vizsgálatok okozta időveszteség és költségnövekedés veszélyére $[3,22]$. A beékelődés szempontjából magas rizikójú csoportba tartozik a beteg, és abnormális CT-leletre számíthatunk, ha például egyéb jelentős társbetegség, korábban elszenvedett központi idegrendszeri megbetegedés, görcsroham vagy más fokális neurológiai kórjel van jelen. Szúrő jellegú CT-vizsgálat az alacsony rizikójú csoportokban nem indokolt. A hemokultúravétel és az első adag empirikus antibiotikum haladéktalan beadása prioritást élvez a CTvizsgálattal szemben [3]. Bakteriális kórok esetén betegeinkben magas arányú volt a dexametazon- és mannitoladás mindkét korcsoportban, ám a kimenetelt ez nem 
javította szignifikánsan az összes bakteriális kórokú betegre nézve. Weisfelt és mtsai tanulmányában a dexametazon egyértelmúen csökkentette a letalitást $S$. pneumoniae okozta meningitisben, de más meningitisek esetén ez a hatás már nem volt ilyen egyértelmű [23]. Ludwig és mtsai tanulmányában a bármely kórokú meningitisek esetén 25\%-os letalitásról számoltak be hazánkban 65 éves kor felett [21 ]. Ez az érték vizsgálatunkban a 29,5\%ot is elérte. Prognózis szempontjából az idős korosztály egyértelmúen esendőbb volt.

A virális kórképek között mindkét korcsoportban a kullancsencephalitis-vírus a legfőbb kórokozó régiónkban. Az 1990-es évek végén észlelt jelentős esetszámcsökkenés ellenére is megőrizte vezető helyét [24]. A HSV-, illetve idősekben és sérült immunitásúakban egyre gyakoribb VZV-neuroinfekciók mellett számos enterovírus-infekcióval is számolhatunk [25-28]. Alacsony a mumpsencephalitis előfordulása a kötelező oltási programnak köszönhetően.

A klinikum tekintetében itt is az időskori tünetszegénység és a felvételkor súlyosabb általános állapot, gyakoribb társbetegségek voltak jellemzők. A liquorvizsgálat során alacsonyabb liquor-fehérvérsejtszámot észleltünk esetükben. Lényegesen több képalkotó vizsgálat történt 65 év felett a diagnózis tisztázására. Nemzetközi tanulmányok alapján a virális encephalitisek esetén a kórházba kerülés és egzakt diagnózis, illetve a szükséges antivirális kezelés megkezdése között lényegesen hosszabb idő telik el, mint bakteriális kórkép esetén $[11,25,26]$ : ez a szegényesebb klinikumnak, a kevésbé jellegzetes liquor- és általános laboratóriumi eltéréseknek a következménye. A herpesencephalitisben az idős élekor, az alacsony felvételi GCS-érték, a kiterjedt elváltozás a képalkotó vizsgálatok során, a megkésett antivirális kezelés magas letalitással jár [29]. Mihály és mtsai 2010-es hazai tanulmánya felhívja a figyelmet arra, hogy a PCR-technikák alkalmazásával jelentősen megnőtt a virológiailag igazolt herpesencephalitisek száma, ám a specifikusantitest-válasz vizsgálata nem hagyható el a csak antitestválasszal diagnosztizált esetek miatt [30]. Az életkor előrehaladtával kullancsencephalitis esetén is rosszabb a prognózis [31, 32]. A kimenetel vizsgálatakor esetünkben nem szignifikánsan, de több idős betegben alakult ki maradványtünet, illetve fordult elő halálozás.

A teljes betegpopulációt tekintve az idős élekor, az alacsony felvételi GCS-érték és a sérült immunitású állapot mind a bakteriális, mind a vírusos eredetû csoportban rosszabb prognózissal járt, ezt támasztja alá több irodalmi adat is $[15,18,19,28,29,31]$.

Tanulmányunk korlátjaként a retrospektív jellegéből adódó tényezőket kell kiemelnünk, amelyek miatt nem minden beteget tudtunk bevonni az elemzésbe, illetve a vizsgált paraméterek egy része nem volt elérhető minden esetben. Ezért az utánkövetés sem volt minden esetben teljes, mert a páciensek egy része nem jelent meg a kontrollvizsgálaton. A helyi epidemiológiai viszonyok nagymértékben befolyásolják a kórokozók megoszlását, így a hazai valós járványügyi helyzet eltérhet a regionális viszonyainkhoz képest.

A jövőre kitekintve, a globális felmelegedés, a fokozott utazási hajlandóság, a migráció és a vektorok terjeszkedése miatt számítanunk kell itthon ez idáig ismeretlen vagy kis esetszámban előforduló kórokozók, gyógyszerrezisztens baktériumok megjelenésére is (Usutu-vírus, Toscana-vírus, Naples- és Sicilian-vírus, Chikungunyaláz, növekvő számú West-Nile neuroinvazív infekció, Borrelia miyamotoi, multidrogrezisztens Mycobacterium tuberculosis) [18, 33-35].

A régiónkban előforduló vezető bakteriális és virális kórokozó ellen rendelkezünk hatékony védőoltással. A 13-valens konjugált Pneumococcus-vakcina 2011 óta érhető el hazánkban a felnőtt lakosság számára. A 2014ben kötelezővé tett csecsemőkori oltás mellett $S$. pneumoniae elleni vakcináció javasolt minden 65 év feletti egyénnek, illetve minden olyan krónikus betegnek, akinek fokozott hajlama van invazív, Pneumococcus okozta fertőzésre (sarlósejtes anaemia, HIV-fertőzés, funkcionális és szerzett léphiány, immunszuppresszív kezelés, krónikus légzőszervi megbetegedés, diabetes mellitus). A KE elleni inaktivált, teljes vírust tartalmazó vakcina 1991 óta érhető el a felnőtt lakosság számára. KE elleni immunizáció általánosan javasolható mindenki számára. 1997 óta az esetszám jelentősen csökkent, nem haladja meg az évi 100-at [24, 31, 35-37].

Tanulmányunk célja az volt, hogy régiónkra nézve incidenciaadattal szolgáljunk a neuroinfekciók gyakoriságát illetően. Információt nyertünk a regionális epidemiológiai viszonyokról, a liquorvizsgálatok mikrobiológiai és kémiai jellemzőiről, a klinikai lefolyásról, a betegségkimenetelről, a várható neurológiai szövődményekrôl és a halálozásról.

Anyagi támogatás: A közlemény megírása és a kapcsolódó kutatómunka anyagi támogatásban nem részesült.

Szerzôi munkamegosztás: F. Zs.: A vizsgálat megtervezése, irodalmazás, adatgyüjtés, adatrendezés, a munka megírása és a társszerzők javaslatára a többszöri átdolgozása. T. E.: Adatrendezés, validálás, adjusztálás, biostatisztikai feldolgozás, az adatok közlésformába rendezése, a szöveg javítása, lektorálása. S. F.: A téma felvetése, az adatgyüjtés ellenőrzése, a téma feldolgozása, a munka teljes felügyeletének ellátása. A cikk végleges változatát valamennyi szerző elolvasta és jóváhagyta.

Érdekeltségek: A szerzőknek nincsenek érdekeltségeik.

\section{Köszönetnyilvánítás}

Köszönettel tartozunk Dr. Gábor Beáta (Markusovszky Egyetemi Oktatókórház, Infektológiai Osztály) infektológus, Dr. Molnár Judit és Molnárné Szakács Andrea (Szombathelyi Mikrobiológiai Labor, SYNLAB) mikrobiológus kollégáknak a készséges együttmúködésü- 
kért, valamint a Nemzeti Népegészségügyi Központ I. Bakteriológiai Osztályán dolgozóknak és a Virológiai Főosztályon munkálkodó $D r$ Barcsay Erzsébet és Dr. Nagy Orsolya kolléganóknek a diagnosztikához nyújtott segítségükért.

\section{Irodalom}

[1] Nudelman Y, Tunkel AR. Bacterial meningitis. Drugs 2009; 69: 2577-2596.

[2] Busl KM, Bleck TP. Bacterial infections of the central nervous system. Curr Infect Dis Rep. 2013; 15: 612-630.

[3] van de Beek D, Cabellos C, Dzupova O, et al. ESCMID guideline: diagnosis and treatment of acute bacterial meningitis. Clin Microbiol Infect. 2016; 22(Suppl 3): S37-S62.

[4] Venkatesan A, Tunkel AR, Bloch KC, et al. Case definitions, diagnostic algorithms and priorities in encephalitis: consensus statement of the International Encephalitis Consortium. Clin Infect Dis. 2013; 57: 1114-1128.

[5] Bookstaver PB, Mohorn PL, Shah A, et al. Management of viral central nervous system infections: a primer for clinicians. J Cent Nerv Syst Dis. 2017; 9: 1-12.

[6] Dorsett M, Liang SY. Diagnosis and treatment of central nervous system infections in the emergency department. Emerg Med Clin North Am. 2016; 34: 917-942.

[7] Tyler KL. Acute viral encephalitis. N Engl J Med. 2018; 379: $557-566$.

[8] Østergaard AA, Sydenham TV, Nybo M, et al. Cerebrospinal fluid pleocytosis level as a diagnostic predictor? A cross-sectional study. BMC Clin Pathol. 2017; 17: 15

[9] Jereb M, Muzlovic I, Hojker S, et al. Predictive value of serum and cerebrospinal fluid procalcitonin levels for the diagnosis of bacterial meningitis. Infection 2001; 29: 209-212.

[10] Chalupa P, Beran O, Herwald H, et al. Evaluation of potential biomarkers for discrimination of bacterial and viral infections. Infection 2011; 39: 411-417.

[11] Michael BD, Sidhu M, Stoeter D, et al. Acute central nervous system infections in adults - a retrospective cohort study in the NHS North West region. QJM 2010; 103: 749-758.

[12] Epinfo Special Issues 2011-2017. [Epinfo-különszámok, 20112017.] www.oek.hu/epinfo [Hungarian]

[13] Lakos A. Lyme borreliosis - lessons learnt from 25years. [Lymeborreliosis -25 év hazai tapasztalatai.] Orv Hetil. 2009; 150 725-732. [Hungarian]

[14] Hungarian Central Statistical Office: Population, demography. [Központi Statisztikai Hivatal. Népesség, népmozgalom.] https://www.ksh.hu/nepesseg_nepmozgalom [Hungarian]

[15] Domingo P, Pomar V, de Benito N, et al. The spectrum of acute bacterial meningitis in elderly patients. BMC Infect Dis. 2013; 13: 108 .

[16] Giorgi Rossi P, Mantovani J, Ferroni E, et al. Incidence of bacterial meningitis (2001-2005) in Lazio, Italy: the results of integrated surveillance system. BMC Infect Dis. 2009; 9: 13.

[17] Hofinger D, Davis LE. Bacterial meningitis in older adults. Curr Treat Options Neurol. 2013; 15: 477-491.

[18] Erdem H, Inan A, Guven E, et al. The burden and epidemiology of community-acquired central nervous system infections: a multinational study. Eur J Clin Microbiol Infect Dis. 2017; 36: 1595-1611.

[19] Calleri G, Libanore V, Corcione S, et al. A retrospective study of viral central nervous system infections: relationship amongst aetiology, clinical course and outcome. Infection 2017; 45: 227 231.

[20] Lakatos B, Prinz G, Sárvári Cs, et al. Central nervous system tuberculosis in adult patients. [Felnőttek központi idegrendszeri tuberkulózisa.] Orv Hetil. 2011; 152: 588-596. [Hungarian]
[21] Ludwig E, Jorgensen L, Gray S, et al. Clinical burden of multicause and pneumococcal pneumonia, meningitis, and septicemia in Hungary. Results of a retrospective study (2006-2011). [Pneumococcus, illetve bármely kórokú pneumonia, meningitis és septicaemia miatti hospitalizáció és halálozás Magyarországon. Egy retrospektív értékelés eredménye (2006-2011).] Orv Hetil. 2014; 155: 1426-1436. [Hungarian]

[22] Aronin SI. Bacterial meningitis: principles and practical aspects of therapy. Curr Infect Dis Rep. 2000; 2: 337-344.

[23] Weisfelt M, van de Beek D, de Gans J. Dexamethasone treatment in adult with pneumococcal meningitis: risk factors for death. Eur J Clin Microbiol Infect Dis. 2006; 25: 73-78.

[24] Lakos A, Rókusz L. The epidemiology of tick-borne encephalitis in Hungary - the role of the vaccines. [A kullancsencephalitis járványügyi helyzete Magyarországon - a védőoltások szerepe.] Háziorv Továbbk Szle. 2011; 16: 38-40. [Hungarian]

[25] McGill F, Griffiths MJ, Bonnett LJ, et al. Incidence, aetiology, and sequelae of viral meningitis in UK adults: a multicentre prospective observational cohort study. Lancet Infect Dis. 2018; 18 : 992-1003.

[26] Bodilsen J, Storgaard M, Larsen L, et al. Infectious meningitis and encephalitis in adults in Denmark: a prospective nationwide observational cohort study (DASGIB). Clin Microbiol Infect. 2018; 24: 1102.el-1102.e5.

[27] Douglas A, Harris P, Francis F, et al. Herpes zoster meningoencephalitis: not only a disease of the immunocompromised? Infection $2010 ; 38: 73-75$.

[28] Kaewpoowat Q, Salazar L, Aguilera E, et al. Herpes simplex and varicella zoster CNS infections: clinical presentations, treatments and outcomes. Infection 2016; 44: 337-345.

[29] Sili U, Tavsanli ME, Tufan A. Herpes simplex virus encephalitis in geriatric patients. Curr Geriatrics Rep. 2017; 6: 34-41.

[30] Mihály I, Kolozsi T, Liptai Z, et al. Experiences with multiplex nested PCR and fluorescent antibody tests in the diagnosis of herpes simplex virus type 1 and 2 acute central nervous system infections. [Tapasztalatok a heveny központi idegrendszeri fertőzések herpes simplex virus- $1 / 2$ diagnosztikájában a multiplex nested PCR- és a fluoreszcens jelzésű antitestválasz-vizsgálat kombinációjával.] Orv Hetil. 2010; 151: 1896-1903. [Hungarian]

[31] Kaiser R. Tick-borne encephalitis: clinical findings and prognosis in adults. Wien Med Wochenschr. 2012; 162: 239-243.

[32] Bogovic P, Strle F. Tick-borne encephalitis: a review of epidemiology, clinical characteristics and management. World J Clin Cases 2015; 3: 430-441.

[33] Lyons J, McArthur J. Emerging infections of the central nervous system. Curr Infect Dis Rep. 2013; 15: 576-582.

[34] Gould E, Pettersson J, Higgs S, et al. Emerging arboviruses: why today? One Health 2017; 4: 1-13.

[35] Moriconi M, Rugna G, Calzolari M, et al. Phlebotomine sand fly-borne pathogens in the Mediterranean Basin: human leishmaniasis and phlebovirus infections. PLoS Negl Trop Dis. 2017; 11: $\mathrm{e} 0005660$.

[36] The guideline of National Public Health Center for vaccination in 2019. [A Nemzeti Népegészségügyi Központ módszertani levele a 2019. évi védőoltásokról. https://www.antsz.hu/data/ cms92651/VML2019_NNK_2019_05_08. pdf [Hungarian]

[37] Kulcsár A. Prevention of infections in patients with absent or dysfunctional spleen: adaptation of international guidelines. [Infekciók megelőzése léphiány és a lép múködési zavara esetén: a nemzetközi ajánlások hazai adaptációja.] LAM 2013; 23: 406411. [Hungarian]

(Toldy Erzsébet dr., Kaposvár, Szent Imre u. 14/B, 7400 e-mail: toldy.erzsebet@gmail.com)

A cikk a Creative Commons Attribution 4.0 International License (https://creativecommons.org/licenses/by/4.0/) feltételei szerint publikált Open Access közlemény. (SID_1) 